\title{
Agata Chabior, Agnieszka Szplit (red.), Ageing and Old Age as a Task - Health, Activation, Development, Integration, Wydaw- nictwo Libron, Kraków 2014, ss. 289.
}

Recenzowana publikacja jest zbiorem artykułów dotyczących problematyki gerontologicznej i działań w zakresie pomyślnego starzenia się, tj. aktywizowania i optymalizowania funkcjonowania tej grupy społecznej w wymiarze fizycznym, psychicznym, społecznym i kulturowym.

Całość woluminu Starzenie i starość jako zadanie - zdrowie, aktywizacja, rozwój i integracja składa się z 19 artykułów podzielonych na cztery części autorstwa specjalistów - pracowników naukowych i praktyków działających w tym zakresie. Pierwszy rozdział: Zdrowie i jakość życia w starości koncentruje się wokół zagadnień zdrowia, jego oceny i wpływu na podejmowaną aktywność w okresie starości. Otwiera go artykuł Agaty Jopkiewicz i Magdaleny Lelonek pt. Gerontopedagogiczny wymiar aktywności fizycznej w zapobieganiu regresji poznawczych $w$ wieku podesztym. Jest on przeglądem badań potwierdzających tezę, że aktywność ruchowa, również w wieku 65+, może pomóc w utrzymaniu, a nawet zwiększyć poznawcze funkcje mózgu, zmniejszając ryzyko związane z występującymi wraz wiekiem zaburzeniami neurologicznymi i chorobami geriatrycznymi.

Biologiczna i społeczna zmienność okresu około menopauzalnego to obszar rozważań kolejnego autora - Agnieszki Przychodni. Tekst stanowi próbę scharakteryzowania przebiegu okresu okołomenopauzalnego w odniesieniu do wybranych zachowań zdrowotnych i stylu życia kobiet. Wskazuje się na silne środowiskowe uwarunkowania przebiegu okresu okołomenopauzalnego, różnorodność i zmienność warunków społeczno-ekonomicznych decydujących o jakości życia kobiet. Autorka wykazała, że w łagodzeniu negatywnych skutków menopauzy istotne znaczenie ma utrzymanie wysokiej aktywności fizycznej i zachowanie prozdrowotnego stylu życia. Na uwage zasługuje też tekst Grażyny Czerwiak, Moniki Szpringer i Mariana Florczyka Niedożywienie problemem klinicznym wieku podeszłego, który jest analizą 
badań pilotażowych przeprowadzonych na terenie miasta Kielce. Wyniki badań doprowadziły do identyfikacji czynników zaburzających żywienie seniorów i pozwoliły na przedstawienie postulatu wdrożenia kompleksowego programu profilaktyki żywienia osób starszych. W kolejnym tekście: Aktywność ruchowa jako forma aktywizacji seniorów Justyna Palacz wykazuje, że aktywność ruchowa osób starszych wpływa na godną i satysfakcjonującą egzystencję oraz stanowi najważniejszy czynnik wpływający na zdolność do samodzielnego życia. Rozdział pierwszy zamyka artykuł Hanny Wiśniewskiej-Śliwińskiej pt. Ocena sytuacji zdrowotnej seniorów - na podstawie badań z terenu województwa śląskiego. Niniejszy artykuł prezentuje opinie osób starszych nt. usług medycznych i opiekuńczych oraz określa stopień przygotowania placówek medycznych do leczenia osób starszych z woj. śląskiego.

Rozdział drugi traktuje o społeczno-kulturowym wymiarze starzenia się i starości. Przedstawiono w nim szereg odniesień do zagadnień egzystencjalnych obecnych w życiu ludzi starszych oraz problemów, z którymi przychodzi zmagać się wielu z nich, takich jak: lęki, cierpienie, poczucie braku sensu życia, a także przemoc i przestępczość doświadczane w starości. Pierwsza z autorek - Marta Wilk w artykule Osoba starsza jako ofiara przestępstwa $w$ przestrzeni publicznej oraz aspekty profilaktyki zjawiska podejmuje ważny problem popełniania przestępstw przeciwko własności osób starszych. Przestępczość dotyczy również ludzi starszych, którzy ze względu na wiek i jego określoną specyfikę są narażeni na to, aby zostać ofiarą przestępstwa. Dlatego też autorka wskazuje na istotę profilaktyki zapobiegania temu zjawisku. W artykule Profilaktyka samobójstw u osób w wieku senioralnym Kazimierz Kopczyński, Magdalena Kaczmarek skoncentrowali się na zagadnieniach mających istotne znaczenie $\mathrm{z}$ punktu widzenia profilaktyki samobójstw u osób w wieku senioralnym. Wskazali na: samotność ludzi starszych i jej związek z depresją i samobójstwem, bilans życia dokonywany przez seniorów i związane z nim tzw. samobójstwo bilansowe, samobójstwo egzystencjalne wiążące się z poczuciem bezsensu ludzkiego istnienia, wczesną interwencję - prewencję suicydalną, rozpoczynającą się nie w starości, ale o wiele wcześniej oraz wykorzystanie podejścia psychologii pozytywnej w profilaktyce samobójstw u seniorów. Kolejny artykuł Izabeli Gomółki-Walaszek pt. Późna dorosłość w obrazie lęku zawiera wyniki badań własnych wśród pensjonariuszy ośrodka pomocy społecznej. Opisała obraz lęku, jaki towarzyszy pensjonariuszom, wykazała zależność pomiędzy poziomem lęku a poczuciem i oceną jakości życia badanych seniorów. Prezentowane doniesienie z badań jest okazją do refleksji nad poczuciem jakości życia, powodowanym lękiem sytuacyjnym, osób w fazie starzenia i starości umieszczanych 
w DPS. Drugi rozdział zamyka artykuł Adama Perza Troska duszpasterska o ludzi starszych. Odnosząc się do eschatologicznego wymiaru starości i starzenia się, wskazuje się na miejsce i rolę posługi duszpasterskiej jako ważnej formy wsparcia w życiu ludzi starszych.

Rozdział trzeci ukazuje uwarunkowania i formy aktywizacji seniorów w jej wymiarze instytucjonalnym i pozainstytucjonalnym, z jednoczesnym wskazaniem na realizowaną przez osoby starsze aktywność także w środowisku wiejskim. Elżbieta Woźnicka w artykule Sytuacja społeczna i aktywność ludzi starszych na wsi poruszyła problem starości na wsi. Ukazała specyfikę starości w środowisku wiejskim i najważniejsze problemy osób starszych. Z kolei Dorota Rynkowska i Katarzyna Błaszczuk w swym opracowaniu Integracja osób starszych w zakresie aktywności społecznej uznały aktywność społeczną za niekwestionowany czynnik wpływający na funkcjonowanie człowieka - seniora w środowisku społecznym. Alternatywą dla wykluczania osób starszych z życia publicznego są inicjatywy na rzecz aktywizacji i wsparcia, poprzez działania na rzecz integracji wewnątrz i międzypokoleniowej w środowisku lokalnym. W opracowaniu przedstawiono działalność Kraśnickiego Stowarzyszenia Inicjatyw Społecznych IMPULS i jego sztandarowy projekt - Centrum Aktywności Seniora alternatywa na samotność, realizowany w ramach Programu ASOS. Ryszard Majer w artykule Aktywizacja osób starszych $w$ środowisku wiejskim, bariery i możliwości opisał podmioty odpowiedzialne za realizację polityki senioralnej w Polsce: począwszy od administracji publicznej, poprzez samorząd terytorialny, kreujący lokalną politykę społeczną, organizacje pozarządowe, mogące realizować projekty i programy, do podmiotów komercyjnych, włączających się w realizację działań na rzecz najstarszych mieszkańców. Kolejna autorka - Anna Stawecka w swoim referacie pt. Twórczość plastyczna i arteterapia jako forma aktywizacji seniorów prezentuje możliwość wszechstronnego aktywizowania seniorów poprzez zachęcanie ich do działań twórczych i kontaktu ze sztuką plastyczną. Dom Opieki Rodzinnej jako nowa instytucja realizująca działalność pomocowa na rzecz osób starych i niepetnosprawnych autorstwa Małgorzaty Porąbaniec jest kolejnym tekstem zamieszczonym $\mathrm{w}$ pracy. W swym artykule autorka dokonuje monograficznego opisu jednej z instytucjonalnych form opieki i aktywizacji życiowej seniorów, jakim jest Dom Opieki Rodzinnej „Hotelik" w Pierzchnicy. Cenną wartość tego zbioru przedstawia rozdział czwarty poświęcony prezentacji dobrych praktyk aktywizowania osób starszych. Zawarte tam artykuły opisują realizowane bądź zamknięte już projekty działań praktycznych, które sprzyjając rozwojowi seniorów, w sposób rzeczywisty wpływają na jakość ich życia. Zostały w nim kolejno omówione: działania 
aktywizujące realizowane przez Wojewódzką Bibliotekę Publiczną w Kielcach. Te treści prezentuje artykuł Anny Lubczyńskiej pt. Biblioteki a czytelnicy seniorzy - na przykładzie Wojewódzkiej Biblioteki Publicznej w Kielcach. Bogatą ofertę aktywności edukacyjnej, artystycznej i społecznej słuchaczy UTW w Częstochowie zaprezentowała Joanna Górna w artykule Aktywizacja społeczno-życiowa seniorów w praktyce na przykładzie Uniwersytetu Trzeciego Wieku przy Akademii im. J. Długosza w Częstochowie. Działalność Kujawsko-Dobrzyńskiego UTW we Włocławku w perspektywie potrzeb edukacyjnych seniorów przedstawiła Renata Brzezińska w tekście Potrzeby edukacyjne seniorów. Z badań nad działalnościq Kujawsko-Dobrzyńskiego Uniwersytetu Trzeciego Wieku we Włocławku. Cały rozdział zamyka artykuł Katarzyny Jas Rola Cieszyńskiego Uniwersytetu Trzeciego Wieku oraz Dziennego Ośrodka Aktywności Seniora w aktywizowaniu osób w okresie późnej dorostości. Opisane dobre praktyki pokazują, że aktywna starość i starzenie się powinno być utożsamiane jako zadanie i czas rozwoju, który przy zachowaniu pewnych warunków, jest nie tylko możliwy, ale konieczny do tego, aby generacja seniorów realizowała swoje życie i aktywność w starości na jak najwyższym poziomie, odpowiadając tym samym na wyzwania współczesności.

Przedstawione artykuły mają przede wszystkim charakter prakseologiczny, w przeważającej części to doniesienia z badań własnych, pozostałe to rozważania teoretyczne budowane wokół doniesień badawczych. Dopełniającą wartością zbioru jest opis ciekawych działań praktycznych w zakresie aktywizowania seniorów.

Wyrażam przekonanie, że oddawana do rąk Czytelnika publikacja będzie użyteczna nie tylko poznawczo, ale także praktycznie, będzie inspiracją do dalszych rozważań, dyskusji i działań nad wyznacznikami pomyślnego starzenia się i wysokiej oceny jakości życia w późnej starości.

Małgorzata Krawczyk-Blicharska 